報文

ORIGINAL PAPERS

\title{
極微量試料用質量分析計の試作
}

\section{A Mass Spectrometer for Ultra Trace Gas Analysis}

\author{
津山斉・岡本潤一*・小池武**・森戸望***
}

Hitoshi Tsuyama, Junichi OKamoto, Takeshi Kolke, Nozomu Morito

(1967年 1 月27日受理)

\begin{abstract}
A mass spectrometer for the analysis of ultra trace samples of gases, particularly noble gsaes, is described. The masss pectrometer is $90^{\circ}$-sector type and its ion trajectory radius is $200 \mathrm{~mm}$. Its main parts are made of stainless steel. The vacum system is extremely clean and easily maintainable. The evacuating system includes a molecular pump or a $3^{\prime \prime}$ oil diffusion pump (Apiezon oil C). By 48 hours evacuation and thorough bakeout, the ultimate pressure of the analyser in the order of $10^{-9} \mathrm{mmHg}$ is attainable. The instrument may be operated in the static mode and the detailed procedure is described. The incremental characteristics of back ground peaks and the diffused peak of argon at $M_{A}=80$ were investigated. Fission product isotopic rare gases and isotopic ratios of uranium were determined.
\end{abstract}

\section{1 緒 言}

同位体存在比を利用した地贸年代決定の研究や原子 核崩塤過程飞打けるフィッンョンガスの定量等の原子 力方面の研究分野飞扣いては, 採取される試料が極め て微是であることが多い。そのため, 砳来の一般犋量 分析飞招いて行われている動作動方式飞よる分析が困 難なため, 今まで秄ら静作動可能な斦量分析計が使用 されてきている1223045)。こよ5な目的のための

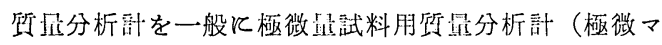
スと略称）と称している。超高点空 $\left(10^{-9} \mathrm{mmHg}\right.$ 以 上）の垁現とその残留ガスの分析が関心をるたれるよ ラになったが，この方面の研究にも低バッククラウン ト，高感度の極微マスの閁発の重琶性が狱感されるよ らとなった。
我々はこの目的に合致した装置をすでに $2 ， 3$ 製品 化してきたが，今回これらに対し大巾な改造を行ない， 例えば超高真空到達時間の短縮を主目的とするなど, 極微マスの间性能化を武みた。

この極微マスの検出感度等の忍用奏験として, ウラ ン然料のフィッンョンガスの定量老行ない, 打もにク リプトン, キセノンとついて検出感度, 分解能等の榆 討を行った。しかしフィッンョンガスの定量に関する 結果と考案は極く簡単に記述する6)。ただ，この奏験 飞扔いて試料中に不純物として存在したアルゴンガス とよると思われる異常ピークが観测されたので，この 現象の解明を試みた。この現象は斦些分析㖕の立場か らは興味のある問題でるあり,この極微マスは静作動 の奏験ができるので, この種の実験研究には好都合な 装置でもある。

* 日立製作所中央研究所那珂分室（茨城県勝田市） Naka Branch, Hitach Central Research Laboraotry. (Katsuta, Ibaraki)

* 日立製作所那珂工場（茨城県勝田市） Naka Works, Hitach Ltd. (Katsuta, Ibaraki)

*** 日立製作所本社（東京都干代田区） Main Office, Hitach Ltd. (Tokyo) 
本試作極微マスの特長としては排気系に分子ポンプ を使用したことが挙げられるが, 到達真空度, 到達時 間, 検出感度, 分解能ともに既報2 3) 4) の極微、スの 性能飞匹敵するものと考兄られる。

\section{2 実験装 置}

\section{1 一般設計事項}

今回の試作の最大の目標は, 全金属製で $10^{-9} \mathrm{mmHg}$ の超高真空を極く短時間で得ることであって，下記の 点について特飞特長をもたせた。

(1) $10^{-9} \mathrm{mmHg}$ 以上の超高真空を目標とするが， 真空度それ自体は現在特に目新しいことではないので, 短時間でこの真空度が得られるようとする。

（2）分析管は加熱焼出を容易にするため, 熱容量の 小さいパイプ形とする。

（3）排気系は，静作動を可能とする。イオン源側お よびィオンコレクター側の両側より排気できるょうと する。

（4）マスには従来用いられていない分子ポンプを便
分析計の試作

用する。また油拡散ポンプとの比較実験が容易にでき るようとする。

（5） イオン軌道半径, 偏向角は従来の標準マス, す なわちそれぞれ $200 \mathrm{~mm}, 90^{\circ}$ とする。

（6）イオン加速電压を $3000 \mathrm{~V}$ と分解能, 感度の増 大をはかる。

（7）二次電子増倍管を使用し感度, 応答時間の向上 をはかる。

\section{2 分析部}

分析部の外観写真をFig. 1 飞示す。分子ポンプの. 排気孔の位置の関係上, 分子ポンプを分析部の真下に 置いたため分析管の位置は床上約 $1.5 \mathrm{~m}$ の高さとなっ た。F!g. 1 は分子ポンプ使用時のものである。油拡散 ポンプを使用するときは, 分子ポンプ接続のフランシ を閉じて，2 個のトラップ間をべロー付パイプで接続 する。

\section{2 .1 分析管}

分析管の偏平部は内径 $42 \mathrm{~mm}$, 肉厚 $1.5 \mathrm{~mm}$ のニテ ンレスパイプを $90^{\circ}$ そ折り曲げ，外厚 $10 \mathrm{~mm}$ K平たく

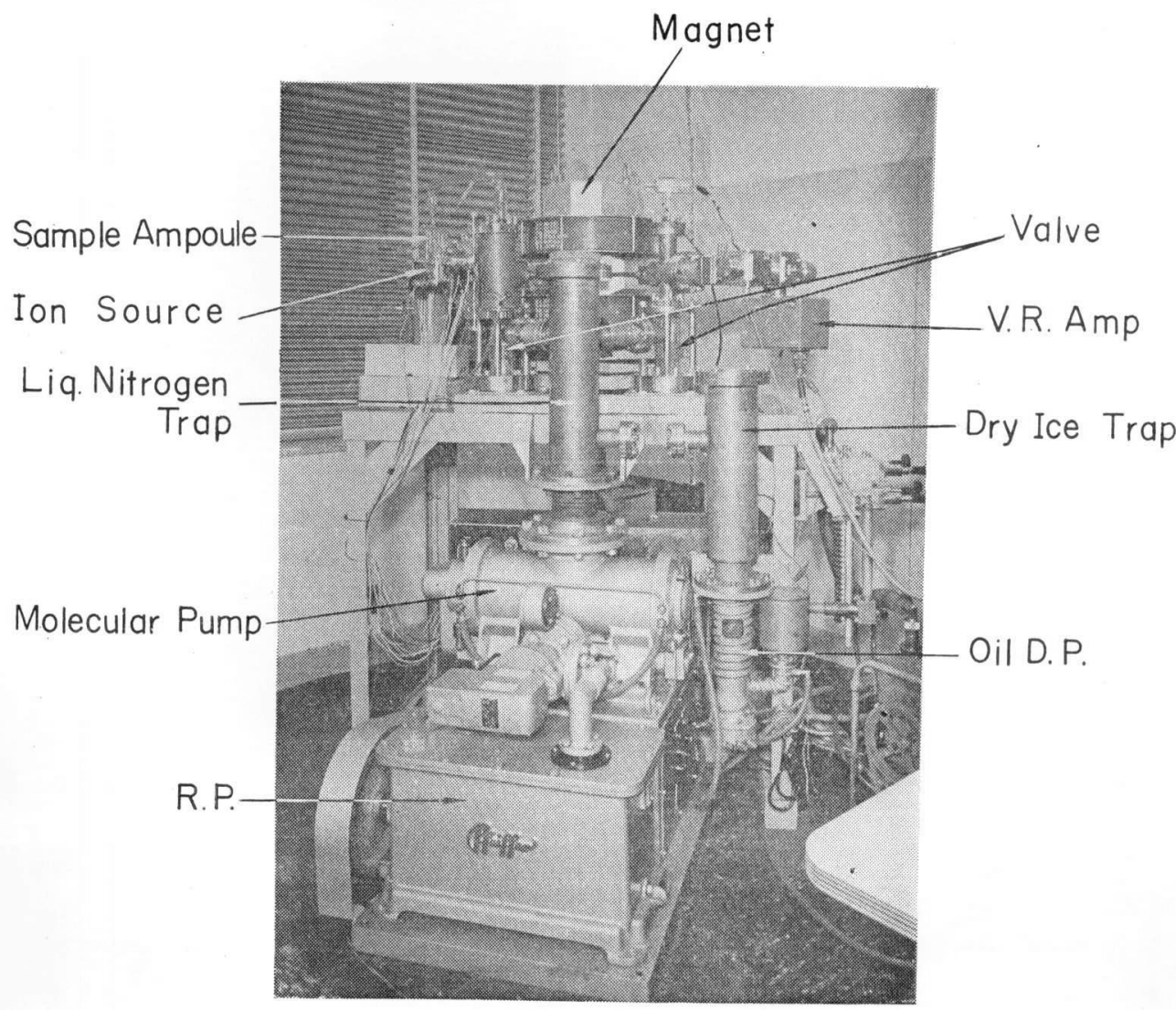

Fig. 1. Photograph of Mass Spectrometer 
つぶしたものである。その泪端をイオン源やイオンコ レクターの取付雨フランシのついた外径 $64 \mathrm{~mm}$ のステ ンレスパイプに熔接して分析管の主要部分とした。こ の分析管は，イオン源とイオンコレクターの耐側飞排

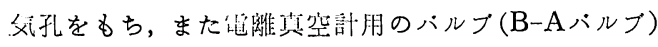
が取付けられる枝管る取付けられている。イオン源は イオン源架台の上飞組立てられたイオン源を分析管の 耐端飞排入して装着する方式であるが，1オン源飞種 々のアクセサリーを取付けるために，本分析管は継手 パイプを取付ければ，標準 $\mathrm{T}-2$ 形イオン源も簡戦に 取り付けられ, また光イオン化用イオン源, 差動排気 系等スペースを要する附属品も容易飞取付けることが できる。

各フランジは金属ガスケットを使用した。この締 付け方は片淔榒形突起, 刘问酒を平面とした。アルミ ニウムガスケットを毁初使用したが, すぐ軟化して交 換時飞問题があるので, 現在は非交換部分は金, 常時 交换部分は銀ガスケット（0.2〜0.4mmの摩さ）を使 朋している。今まで金属ガスケット用の締付部の方式 扣よび形状等についてはいるいる発表されているが, この方式は工作法とその精度が余り㬝密を要しないこ と扣よび修理が容易であることが特長である。薄いガ スケットの場合には 2 枚霆ね合せてもよく，またガス

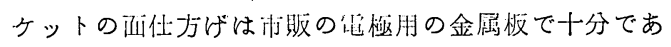
る。

ガスケットからの真空泌れは, 締付けフランシが均 等飞抑えられている限りまず問題はなかった。第 1 回 の燅出しの後飞扢こる聲的歪み飞よる洩れは, 一寸の 槌締めをすることとょり大部分解決された。

\subsection{2 霆磁石}

電磁石の強度は6500ガウス以上を得ることを目標と した。分析管の曆さ $10 \mathrm{~mm}$ であるので, 電磁石のギャ ップは $12 \mathrm{~mm}$ とした。イオン加速電在 $3000 \mathrm{~V}$ K対し $\operatorname{maxM} / \mathrm{e} 300$ が测定できるようにした。電磁石は, 分

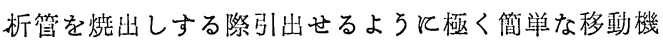
蓝を採用した。また分解能調整時に, 左右, 回転, 上 下もごく簡単な機權で粗微動できるようになっている。

\subsection{3 イオン源とイオンコレクター部}

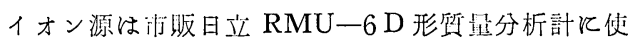
用されていた T-2H 形イオン源である。これの性能, 槛造はすで飞報售てされているので説明は省略する。

イオンコレクター部は初め固定位醞, 固定幅のコレ クタースリット, 二次地子サプレッサー, ファラデー ケーシからなるものを使用した。コレクタースリット 《終始 $0.5 \mathrm{~mm}$ のものを使朋した。その后装置が
$10^{-9} \mathrm{mmHg}$ の超高真空がえられるようになったので 二次笔子增倍管を取付けた。この二次䇝子增倍管は $\mathrm{Ag}-\mathrm{Mg}$ 製で電極10段, 全印加電王2000V K対して利 得約 $10^{4}$ であった。後段は日立AU-12形VRアンプを 用いた。染音レヘルはイオン笪流飞換算して $10^{-18} \mathrm{~A}$ の桁であった。

\section{3 排気系}

極微マスは，超高管空を得ることが第一の目的でる あるので特にその点に考虑をはらって設部した。本試 作の排気系の系統図をFig. 2 に示す。その特長とし て次の点があげられる。

(1) 静作勒用の主バルブはイオン源側, イオンコレ クター側の 2 ケ所に取付けた。

（2）分子ポンプを採用し，これにさらに液体望溹卜 ラップが使用できるようとした。

(3) 油拡散ポンプと分子ポンプとを容易飞交換でき るょうにした。

主バルブ（静作勘ハルブ）はステンレス製のパイプ 状の円錐面飞然酸薪銅球が雨入されて進断する方式で, 原理的な榑造は阪大極微マス1のものと阔じ Hintenberger 方式である。バルブは分析管等加熱排父時に は閁いたままで使用し, 室温に下げてから閒明の操作 を行うようとした。

使用した油昖散ボンプは東京基笠 OF120 形でア ピエゾンCを使用した。

分子ポンプは, Fig. 1, Fig.2 飞ボしたが Pfeiffer 社（西独）のTVP500形を使用した。このポンプは回 転子が 1 分間 16,000 回転するもので, 排気速度は 500 $\mathrm{m}^{2} / \mathrm{h}$.所要電力量は $330 \mathrm{~W}$ である。

分子ポンプの特徴として謳われている点を次に列举 する。

（1）油などの蒸気のない高真空がえられる。

（2）あらゆる種類のガス，蒸気を一様に排気する。

（3）急に大気玨になっても故障しない。

（4）排気速度の圧力特性が, 広領域で極めて平担で ある。

このポンプ単独のテストを行なった結果, 短時間で $10^{-9} \sim 10^{-10} \mathrm{mmHg}$ 飞到達することがわかったので， 分析計に取付けた。本ポンプは回転数が大きいために よる騷音が大きく，防音装置が伹いので耳障りな感じ を淁けるのは矢であるが，操作ぼ極めて䉮便である ので使い良い長所をもっている。

\section{4 試料導入法}

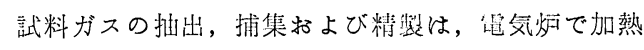
できる全ガラス製の武料ガス抽出精製装置で行なわれ 


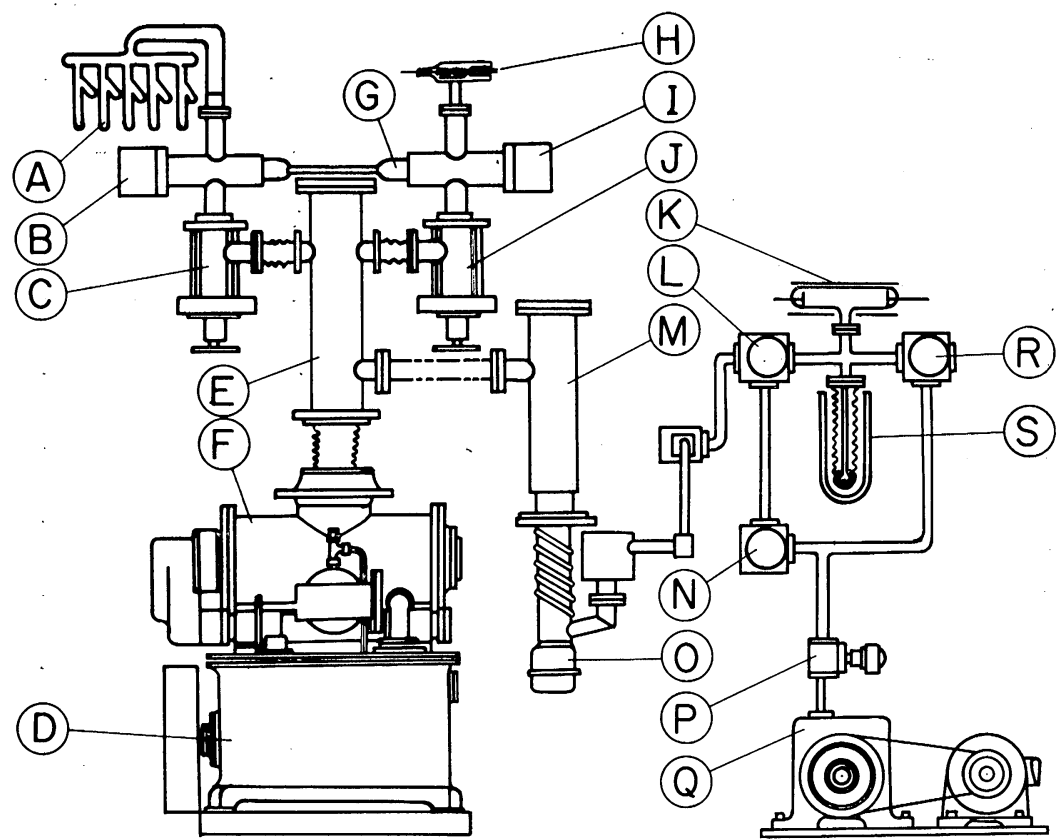

Fig. 2. Schematic View of Vacuum System

A: Ampoule for Sample, B: Ion Source, C: Valve, D: R.P., E: N Trap,

F: Molecular Pump, G: Analyser, H: B-A Gauge' I: Collector, J: Valve,

K: Geissler Tube, L: Valve, M: Dry Ice Trap, N: Valve, O: D.P., P: Valve,

Q: R.P., R: Cock, S: Absorption Trap.

る。鉱物または照射核然料試料より放出される陚料ガ スは,アルゴン, クリプトン，キセノンであるので， 不必要なガス成分は固体炭酸トラップ, チタンフィラ メント，タングステンフィラメント，金属カルンウム 等により取除かれる。精製された試料ガスは, ブレイ カプルショイントの付いたアンプル内值接，または 活性炭飞吸着せしめてアンプルへ封入する。この試料 アンプルは Fig. 2 飞示すごとく值接分析管に取付け て, 分析管を排気後使用可能の真空度になってからブ レイカプルショイントを鉄片で破り静作動中の分析管 内飞直接導入する方式を今回は用いた。この方式は試 料の導入量の調整ができないが，適度の標準試料を導 入すれば，真空度の読みから，同位体稀釈法を用いず 炑直接定量することも可能である。

\section{5 電源部}

本試作マスの電源部は前報7つのとほとんど同じであ るので, 極く簡単にそのうちの主なものの仕様のみを 述べる。

\subsection{1 イオン加速電源}

常用 $3000 \mathrm{~V}$, 最高 $4000 \mathrm{~V}$, 最低 $1000 \mathrm{~V}$ で5段切換と した。穴定度は $2800 \mathrm{~V} て ゙ 10^{-4}$ 程度, それ以上では $10^{-3}$ 程度であった。

\subsection{2 電磁石励磁霄源}

励磁電流 10 270 $\mathrm{mA}$ を連紩的に走查できる。同位 体存在比を测定する場合には, 一般に $5 \sim 10$ 回繰り返 しスペクトルを記録するので自動繰り返し走查ができ るようとした。また繰り返し回数を指定して打くと， 希望の回数だけ繰り返し, 終ると記録計の紙送りも止 まるようとしてある。

\subsection{3 分析管加熱電源}

分析管は, $2 \mathrm{~K} \mathrm{~V}$ の大容量低電王トランスで直接通 電することにより加熱される。分析管弯曲部の温度は これマより $350^{\circ} \mathrm{C}$ 以となる。他の部分も熱伝導によ り $80 \sim 200^{\circ} \mathrm{C}$ 位飞加熱されるが酸水素バーナーにより 燅出しを行なった。

\subsection{4 イオン電流検出部}

実験の初期には Cary の31形VRアンブを使用した。 検出電流は10-16Aであるがあまり時定数が大きい(10 秒）ので不便であった。たまたま開発中であった 2 次 電子增倍管が使用できるようとなったので, 日立製 $\mathrm{AU}-12$ 形 VR アンプ（検出電流 $1 \times 10^{-15} \mathrm{~A}$, 高抵抗 $1 \times 10^{12} \Omega$, 応答速度 2 秒） と日立VKP-21形 $(10 \mathrm{mV}$ full scale）記録計を組合せて使用した。 


\section{3 実験結果}

\section{1 予備調整}

装置の予储調整の日的で，分解能と感度飞ついて簡 単飞検邻を行った。また表西鍳離形イオン源を用いて

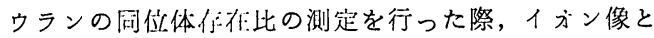
くにピークの被引き（cross talk）飞真空度の及ぼす 影辫について奏駼を行った結果について報告する。

\section{1 .1 水銀スペクトル}

分解能チエックとして水銀のスペクトルを用いた。 イオン加速管褯3000Vで，全電子笔流を $60 \mu \mathrm{A}$ として 実験を行った。武料溥人系の水銀マノメータ一の常温 蒸㸚死をガスリークを通して導入したときのスペクト ルを Fig. 3 に示す。

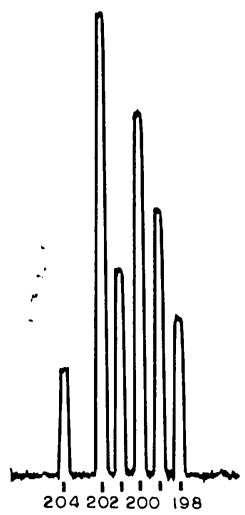

Fig. 3. Mass Spectrum of Mercury

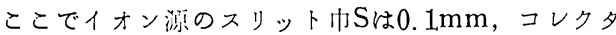
ースリット巾Sdは 0.5mm である。 M/e198のピーク で筑出した失测分解能 $\mathrm{R}_{0}$ は約 560 となり，ピークの形 状から算出されるビーム川BWは 0.18mm で, 全収差 巾こは $0.08 \mathrm{~mm}$ 位と考えられる。このときピークの裾 巾での些测分解度は230である。

\subsection{2 アッゴンスペクトル}

次にアルコンンガスを渻入して得られたスペクトルを

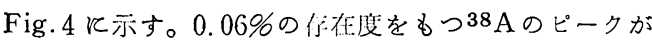
約 $15 \operatorname{div}$ 测分されているから，0.3 div を㭘出限界と しても10ppmの感废を示していることがわかった。こ の增巾器の入打抵抗は $10^{10} \Omega$, 全昏子留流は $60 \mu \mathrm{A} て$ あるから，さらにこれらを增大して $1 \mathrm{ppm} の$ 感度まて 们上させることは浴易であると考えられる。40 $\mathrm{A}^{+}$の ピークの裾が38A飞影薌する割合は約 $2 \%$ ある。

3.1. 3 ウワンのスペクトル飞打ける其空度と裾と の関係

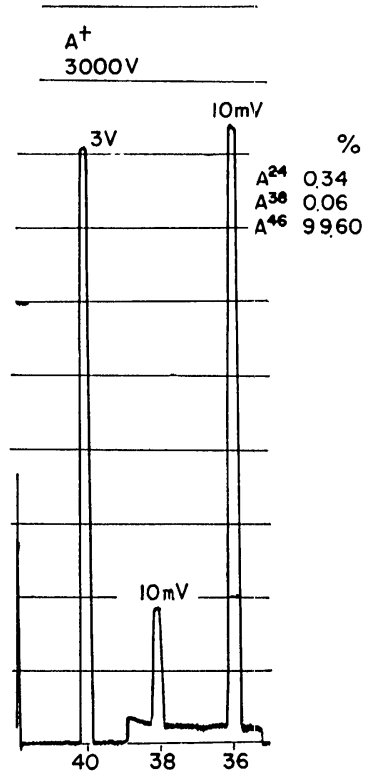

Fig. 4. Mass Spectrum of Argon

表面電離形イオン源を用いてウランの䦌位体存在比 の测定を行った際に，大ピークの椐引き直と真空度と の関係がこの装置でかなり明快飞綃諭された。大ピー クの裾引きが近接ピークのベースに重琹することは测

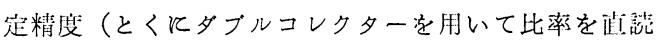
する测定法の埸合)・偠影张を及ぼすので, 極力裙引 きを少くすることが望ましい。この原因は一種の散乱 現象であると考えられるが，令までそれを记訊する確 たる箺験結果が示されていなかった。

われわれ幾多の笑験の絬果, 裾引きの畏は洁空度に 最も大きく徏存することが推尘されたので，本装置が 静作動可能であることを利用して息空度との関係につ いて検期を行った。Fig. 5 は真背度が裙引き是に及ぼ す影䱜について实験したスぺクトルである。排父しな

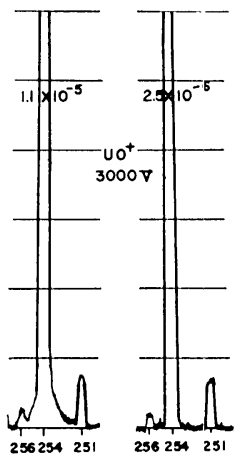

Fig, 5. Spectra of $\mathrm{UO}_{2}{ }^{+}$ 
がら $2.5 \times 10^{-6} \mathrm{mmHg}$ の真空度で測定したのが右側, 静作動バルブを閉ぢて $1.1 \times 10^{-5} \mathrm{mmHg}$ の真空度に なった時のが左側のスペクトルである。真空度 1 标の 違いがかなりはっきり裾引量飞影響することが立証さ された。この対策としては, イオン源を開放的な構造 飞すること，電極から放出されるガスをあらかじめ十 分放出させること, またはイオン源の近くに液体窒素 等のコールドトラップを打く等して真空度を向上させ るととが重要である。

トリッブルフィラメントの場合, レニウムリボン $\left(0.03 \times 0.8 \mathrm{~mm}^{2}\right)$ をイオン化フィラメントとした。 $6 \mathrm{~A} て ゙ 2205^{\circ} \mathrm{C}$ であった。1オン源内に組み込み $5.8 \sim 6$ Aで使用した。試料フィラメントにはタンタルリボン $\left(0.025 \times 1 \mathrm{~mm}^{2}\right)$ を使用した。シンクルフィラメント 法の場合には上記タンタルリボンを使用した。

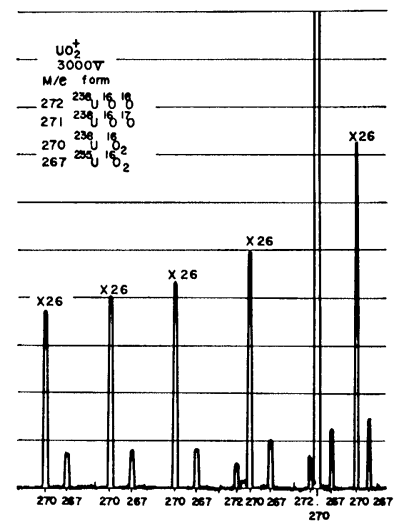

Fig. 6. Mass Spectrum of $\mathrm{UO}^{+}$

かくして十分の注意をはらって得られた $\mathrm{UO}_{2}{ }^{+}$のス ペクトルをFig. 6 と示した。眓に見るごとく裾引き の問題は完全になくなった。ウランの同位体存在比を 表面電離法で測定した結果を Table 1 飞示す。シン グルフィラメント法ではイオン量を長時閪一定に保つ のに苦心した。トリップルフィラメント法ではイオン 量を多くすることができたが，幾分分解能が低下し， また各筐極に与える電压の調整が面倒であった。数少 い㬰験ではあるが，タンタルリボンとよるンンクルフ イラメント法がイオン量, イオン量の安定性, 分解能, 分析結果の再現性等で最もすぐれた結果がえられた。

\section{2. 真空特性とバックグランド}

\section{2 .1 排気操作と到達真空度}

装置組立当初はメタルガスケットの締付け不良から 各所の小リークが重㽪してリーク箇所の検出に苦心し た。括もとアルコールを使用してB-Aゲーシの変化か
Table. 1. Measured Isotope Ratios of $238 \mathrm{U} / 235 \mathrm{U}$. S: single filament T: triple filament

\begin{tabular}{c|c|c}
\hline \hline Mean S (\%) & Deviation (\%) & Filament \\
\hline 0.712 & \pm 0.003 & $\mathrm{~T}$ \\
\hline 0.708 & \pm 0.006 & $\mathrm{~S}$ \\
\hline 0.203 & \pm 0.005 & $\mathrm{~S}$ \\
\hline 0.203 & \pm 0.004 & $\mathrm{~S}$ \\
\hline 0.209 & \pm 0.0008 & $\mathrm{~T}$ \\
\hline 0.201 & \pm 0.002 & $\mathrm{~T}$ \\
\hline 0.460 & \pm 0.012 & $\mathrm{~S}$ \\
\hline 0.433 & \pm 0.003 & $\mathrm{~S}$ \\
\hline 0.438 & \pm 0.002 & $\mathrm{~S}$ \\
\hline 0.395 & \pm 0.002 & $\mathrm{~S}$ \\
\hline 0.431 & \pm 0.004 & $\mathrm{~S}$ \\
\hline 0.460 & \pm 0.006 & $\mathrm{~T}$ \\
\hline 0.868 & \pm 0.007 & $\mathrm{~T}$ \\
\hline
\end{tabular}

ら备所のリークを探した。 $2 \times 10^{-8} \mathrm{mmHg}$ 程度までは ごく簡単飞到達するが，それ以上には仲々上らなかっ た。現在では極めて簡単な操作によって容易に 1.5 $3 \times 10^{-9} \mathrm{mmHg}$ の目的とする超高真空飞到達するので, この場合の排気操作とついてのべる。油拡散ポンブの 場合も分子ポンプのそれと大差なかった。

一系列の試料の測定が終って，次の試料と交換する ときは, 装㯰の真空を破ってガラス細工を行なうので, 分析管全体に，空気と水分か入ることになる。試料取 付けが終れば，油回転ポンプで排父し，罢状なければ 分子ポンプ（または油拡散ポンプ）を動作させる。

分子ポンプならば15分, 油拡散ポンプならば約 1 時 間で $1 \times 10^{-5} \mathrm{mmHg}$ 飞達するから，ここで分析管の 焼出しを行な弓。約 1 時間後分析管の中央部が $350^{\circ} \mathrm{C}$ 位になってから液体窒素トラップ, 配管, 試料部を水 素バーナーでかなり入念にあぶって焼出をつづける。 その状態から10分位後にB-Aゲージ働かせて真堂度 を测定すれば，大概 $2 \sim 7 \times 10^{-6} \mathrm{mmHg}$ となる。この 際B-Aゲーシの焼出しも十分行って抢くことは重要な 操作であった。次とイオン源加熱ヒーターをつけて1 オン源の焼出しを行なう。この操作を行ってから真空 度が $10^{-} \mathrm{mmHg}$ の杕飞入るのに約 1 時間かかるが，烧 
出し中に $5 \times 10^{-7} \mathrm{mmHg}$ 位になれば，烧出し温度を若 干下げて終夜通琶を行な3。翌朝になると $5 \sim 7 \times 10^{-7}$ $\mathrm{mmHg}$ Кなっているし, 終佼通䇝をしない場合です

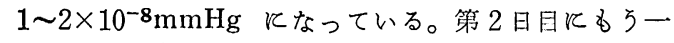
度同じ操作を行なってから烧出しを止めて徐冷すれば 真空度は 3 8 $8 \times 10^{-9} \mathrm{mmHg}$ 飞到達する。かくして

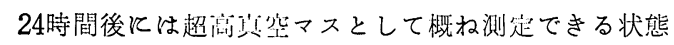
になる。この埸令, 分子ポンプでは液体峌榇トラップ を使用しなくてもこの程度の其空度飞達するが, 油拡
散ポンプの場合には除冷時飞使用した。1.5 2×10-9 $\mathrm{mmHg}$ の真案度は分子ポンプの場合第 3 日目の朝え られた。油拡散ポンプの場合の到達兄空度は $6 \times 10^{-9}$ $\mathrm{mmHg}$ であった。ただし分子ポンプの場合でもイオ ン源用加熱ヒーターを入れイオン源を加熱している狀 態では 2 3 $310^{-9} \mathrm{mmHg}$ が到避真空度であった。

以上のよう飞分子ポンプでも油抎散ポンプでも2

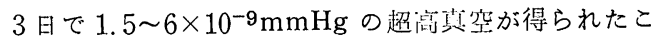
とは，大形金属分析管としては所期の目的を達成した

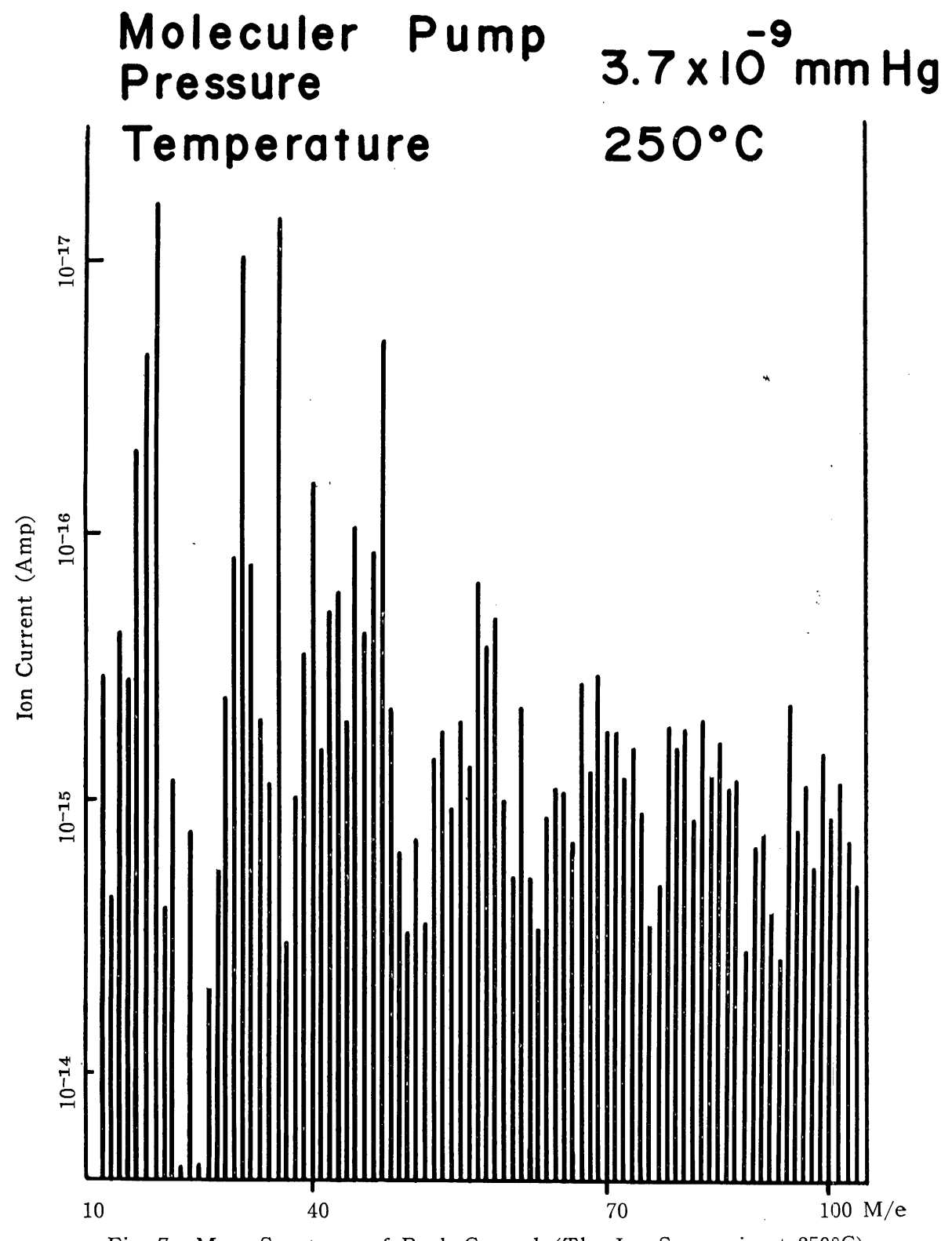

Fig. 7. Mass Spectrum of Back Ground (The Ion Source is at $250^{\circ} \mathrm{C}$ ) 
るのと考えられる。

\section{2 .2 動作動時のバックグランド}

動作動の場合, $10^{-9} \mathrm{mmHg}$ の真空度飞打いても, ハックグランドは大部分イオン源より生ずるるのと思 われる。たとえば，イオン源の加熱用ヒーターを使用 してその温度を約 $250^{\circ} \mathrm{C}$ そした時のバッククラランドの スペクトルをFig. 7, ヒーターなしでイオン源温度を 約 $150^{\circ} \mathrm{C}$ Kした時のハッッククランドのスペクトルを Fig. 8 亿示した。いずれも2 次電子增倍管を用いて测 定した。Fig.7, Fig.8 を比較すれば, イオン源温度 をあげると炭化水素と思われる高質量のガスが大量に イオン源から放出されることがわかる。Fig. 7 は M/e

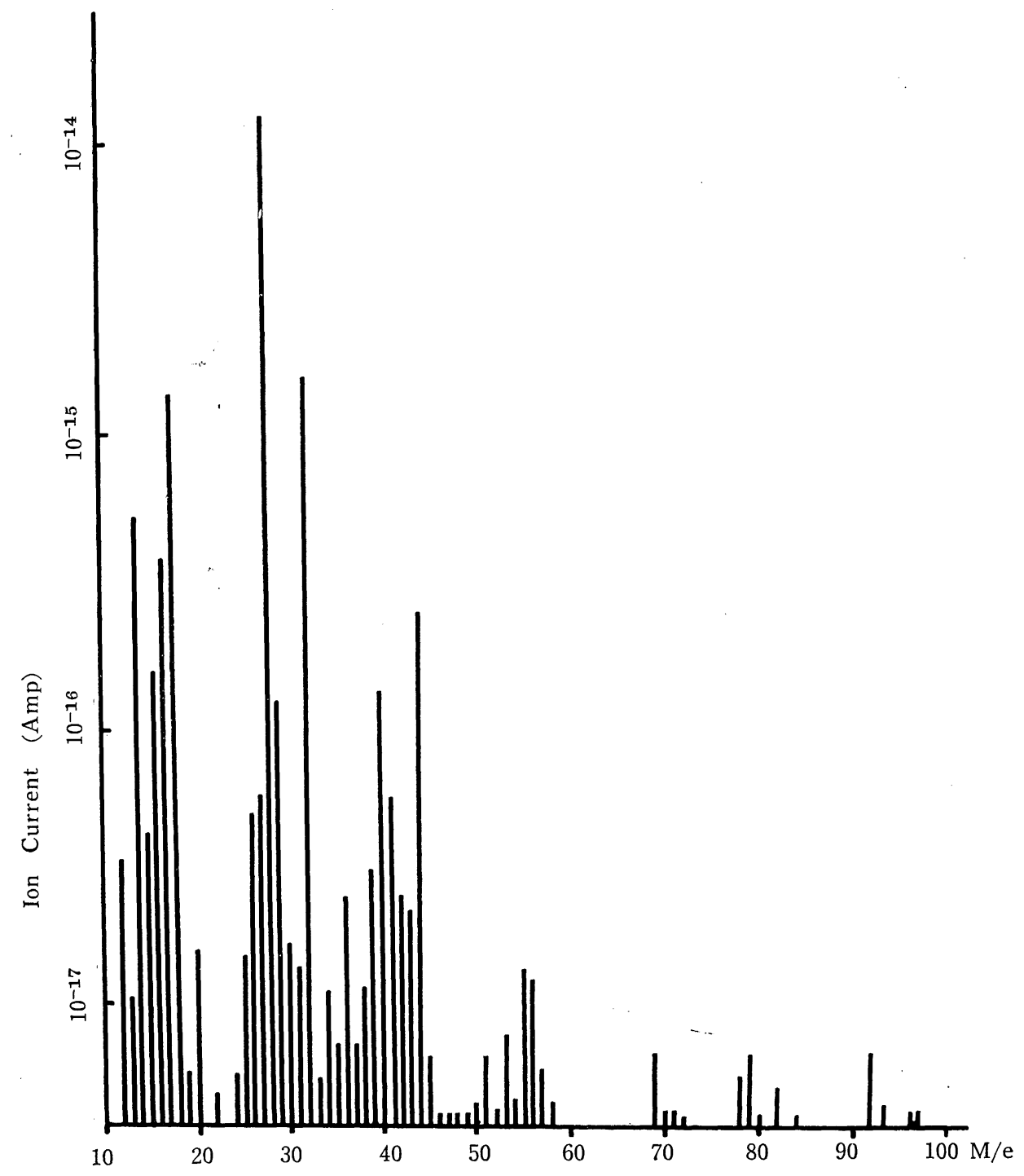

100 をでのイオンしか示さなかったが実際にはM/e200 まで同様のイオンが検出された。

低温度のときは, 一般飞低質量側の炭化水素類の1 オン強度は高温のときの 100 分の 1 程度であることが わかる。とくと低質量側で注目されるのは, 無機ガス ではM/e32のピークの举動である。イオン源が高温の ときは，極めて顕著に現われた。多分 $\mathrm{O}_{2}+$ であろらが， その根源については全く不明である。しかし実際には， 静作動分析ではイオン源を加熱しないで测定するので 一応問題としないこととした。このスペクトル中の大 きなピークはよく知られているよ5と炭酸ガス $(\mathrm{M} / \mathrm{e}$ $44)$, 一酸化炭素ら $(\mathrm{M} / \mathrm{e} 28)$, 水 $(\mathrm{M} / \mathrm{e} 18)$ と酸素

Fig. 8. Mass Spectrum of Back Ground (Ion Sourceat $150^{\circ} \mathrm{C}$ ) 
(M/e 32) であった。

極微マスの1オン源として，本実験飞使用した $\mathrm{T}$ 2 形イオン源は, 㳺容是が大きく複雑な構造をしたも ので必ずしも適当ではなく，本格的な実験を行なうた

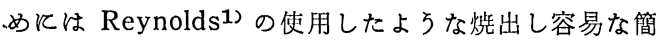
易形が望ましいと洘える。

\section{2 .3 将作動時の圧力変化とバッククランド}

真穵成が $1.5 \times 10^{-9} \mathrm{mmHg}$ となったときから，静 作動バルブを阘じて，分析管内の時間的な圧力変化を イオン源の温度条件をかえて, B-Aゲーシで測定して 得た結果をFig. 9 と示した。静作動バルブを閉じると,

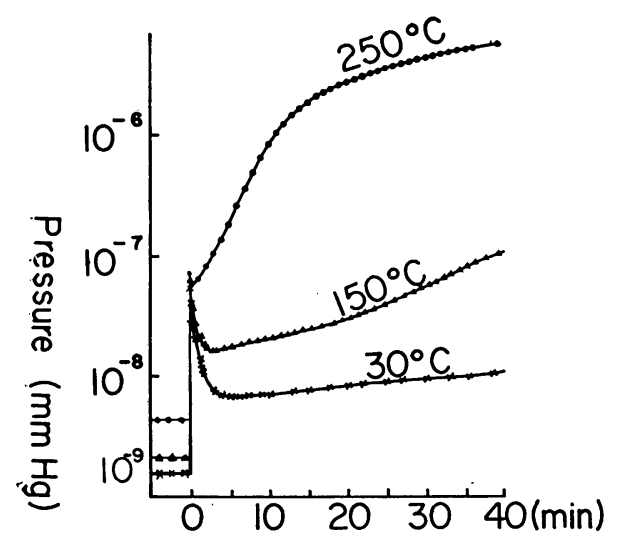

Fig. 9. TimeDependencyof Analyser

Pressure Under Static Operation

ハルブの金属同志の“きしみ”からガスが放出して， 常飞一旦 $6 \sim 7 \times 10^{-8} \mathrm{mmHg}$ 飞真究度が低下する。し かし極く短時間で少しょくなり, その後次第に真些度 が低下する。一度よくなるのはB-Aゲーシの附近の放 出ガスの排父作用によるものと思われる。イオン源の 各ヒーターを墈かせていないときに静作動を行なうと， 30分䦌は $10^{-9} \mathrm{mmHg}$ を保つのに，イオン源のエミ ッンョン用ヒーターをとるすと扣扣むね 1 桁わるく， 10-8 mmHg の桁まで低下する。さら飞加熱用ヒータ 一を僛かせたときは, かなり早く点空度は低下し, 約 15分で $10^{-6} \mathrm{mmHg}$ の桁飞低下する。これはイオン源 からガスが放出されていることを泟明するものである。

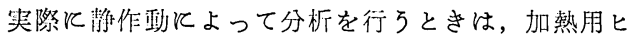
ーターをつけない中央の曲線の場合を使うのであるが, その時のバッククランドはメタンの外は大体無機ガス である。静作政洔飞㱼も急速飞增大するのは $\mathrm{M} / \mathrm{e} 28 の$

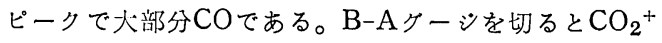
は增大し $\mathrm{CO}$ は逆飞減少する傾向を示し, $\mathrm{CO}^{+}$の大部 分は $\mathrm{CO}_{2}$ のフラクメントの外飞熟分解など，と飞かく
B-Aゲーシの丢熱フイラメントに関速すると考えられ る。

\section{2 .4 分子ポンプの性能}

分子ポンプを使用した経験から次のことがわかり， 睤是分析計に十分使用できるることがかった。

(1) 到達真空度は, 油拡散ポンプが $6 \times 10^{-9} \mathrm{mmHg}$ に刘し, 分子ポンブは $1.5 \times 10^{-9} \mathrm{mmHg}$ で, 液体 窒素を使用しなくても $3 \times 10^{-9} \mathrm{mmHg}$ であった。

（2）大気珠から排気して $10^{-6} \mathrm{mmHg}$ 飞到達するの 飞約10分位である。油拡散ポンプでは約 2 時間要 するのと比べ，特筆すべき長所である。

（3）当初心配された振動は, 排管の一部をへロローで 接続することにより除去することができた。

（4）譟操作により突如として大気王にしたことがあ るが，問題なかった。

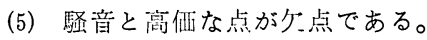

\section{3 極微試料の測定}

極微試料の分析としては，核分裂放出ガスの分析を 行った。分析結果については谷口等6)が報告している のでごく簡単に述べるに止める。

ウランの分裂過程に怙いて, 熱中性子はU235によ つて捕獲されて，これが $\mathrm{U}^{236}$ になり，U236は 2 筐の フラクメントに分裂する。

この過程は次式で示される。 $\mathrm{U}^{235}+\mathrm{n} \longrightarrow \mathrm{U}^{236} \longrightarrow \mathrm{Z}^{A m 1}+Z^{B m 2}+\nu \mathrm{n}$

ここで $Z_{1}+Z_{2}=92, m_{1}+m_{2}+\nu n=236$

そして初期の崩壊生成物 $\mathrm{A}, \mathrm{B}$ はさら飞 $\beta$ 崩壊を行 ない,ついに桇定同位体になることが知られている。 核分裂放出ガスとして，キセノン，クリプトンがある。

二酸化ウラン $10 \mathrm{gr}$ HTR 照射枃で $100 \mathrm{KW}$ 飞おい て約11時間照射し，11ケ月放置した武料中 $6.8 \mathrm{gr}$ を真 空加熱抽出したガスをアンプルにつめたものを使用し た。静作動された分析管に等入, 得られたスペクトル を Fig.10 と示す。Fig. 11 飞武料中の不純物のス ペクトルを示す。クリプトンおよびキセノンの同位体 存在比はいずれる天然のものとは全く買なるし，また Thode 等8) の結果ともよく一致していることから核 分裂放出ガスであることが明かである。クリプトンと キャノンのイオン化効率がほぼ闰等と考えてキセノン はクリプトンの約10偣生成したことになる。不純物と して, $\mathrm{CO}_{2}, \mathrm{~A}, \mathrm{CO}, \mathrm{CH}_{4}$ であるが, $\mathrm{CO}_{2}, \mathrm{CO}, \mathrm{CH}_{4}$ は静作期中と增大するすので陚料の不純物の大部分は アルゴンである。

キセノン拈よびクリプトンの榴染ガス（一定是）を アンプルルつめ静作動を行つて各成分の感度を求め放 
Vol. 15, No. 2, June 1967

出ガスの絶対量の半定量分析を行なった。放出ガス全

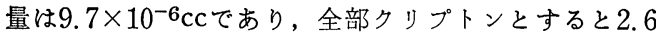
$\times 10^{14}$ 箇に相当する。定量分析の結果クリプトンの総 和 $\left(\mathrm{K}^{83}, \mathrm{~K}^{84}, \mathrm{~K}^{85}, \mathrm{~K}^{86}\right)$ は $3.7 \times 10^{-7} \mathrm{CCNTP}$, キ

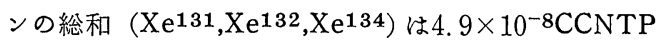
で，クリプトン，キセノンの総和は4. $2 \times 10^{-7 C C N T P}$ であった。

この分析法は未だ予備実験の域をでていないので今 後さらに詳細な検討を行う予定でいる。

\subsection{2 本装置の検出限界}

天然クリプトンの標準試料から，この装置の検出限

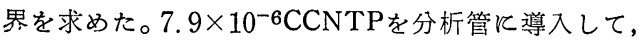
$1 \mathrm{div}$ が $3.4 \times 10^{-15} \mathrm{~A}$ に相当する增幅感度で測定した。
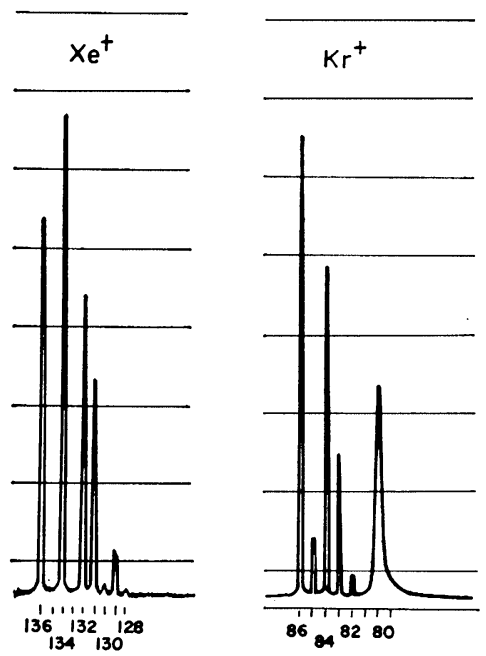

Fig. 10. Mass Spectra of Fission Gases このときクリプトンの全イオン量が273div测定された。

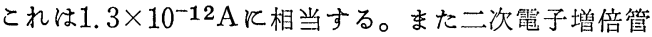
を用い 104 利得をかせぎ，0.2divを検出限界とすると $1.5 \times 10^{-12} \mathrm{CCNTP}$ となる。原子数で約 $3.9 \times 10^{7}$ 箇 となりReynolds ${ }^{12}$ の榆出限界飞匹敵する性能である といえょう。

\section{4 質量数80の異常ピーク}

核分裂放出ガスのスペクトル (Fig. 10) 中, M/e80. の位置にブロードな異狀ピークが測定された。質量ス ベクトルマ打いて,一般にイオンの $\mathrm{M} / \mathrm{e}$ 整数である が，端数の質量位置に，また裾を引いたイオンが認め られることがある。ダブレット，トリップレット等の 多電荷イオンを除いてはこのイオンの生成される原因; としては一般に真空度が悪い場合とか，真空が良くて もイオンが準安定狀態になり易い場合などのようと二 次過程のイオン化現象で招こると考えられている。

この場合他のピークは正常ピークであるのに, この ピークのみが特異な形狀をしていることから，このピ 一クは試料の不純物として圧倒的多量飞混入している アルゴンガスによるものと考えられ，その究明を行っ た。M/e20，40，80のピークの相互関係を検傠した結 果，ほぼ妥当と思われる結論が得られた。 次の項目飞ついて実験した。

(1) 圧力をかえる。

二次反忍により生成されると考えられる $\mathrm{M} / \mathrm{e} 80$ ” のイオンの生成量が, 王力 $\mathrm{P}$ 亿対し二次関数的変 化をするかどうか。

（2）イオン加速電圧をかえたとき イオンの運動エホルギーが衝突反応飞どの程度影

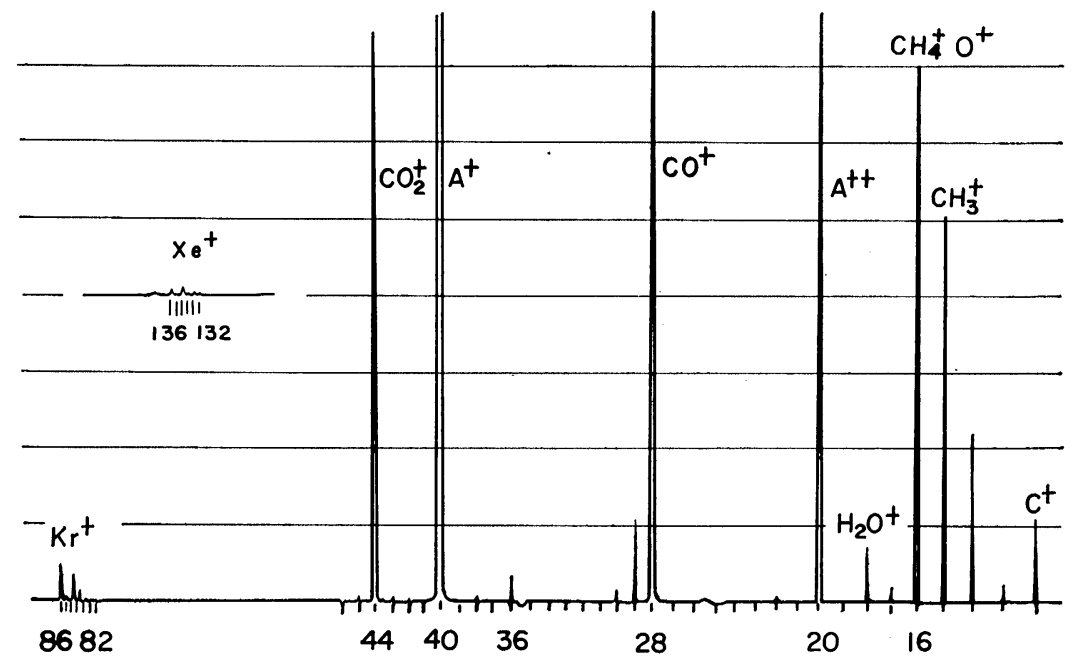

Fig. 11. Mass Spectra of Impurities of Fission Gases 
響するか。

(3) イオン化朢圧をかえたとき

イオン化型玨により，生成されるイオンの種類が

異ってくるから，生成される量と啠とに対して，

直接的な决め手となるかどうか。

$\mathrm{M} / \mathrm{e} 80$ のピークとして, 一つは $\mathrm{A}_{2}+$ の生成が考えら れる。または Mattauch等9)が既飞イオンを解析して いるようと

$$
\mathrm{A}^{++} \longrightarrow \mathrm{A}^{+2-1}
$$

のごとき荷㴈転移の現象である。今初速度をるたな

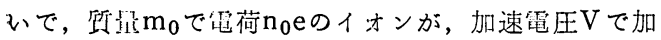
速され，速度りを持ってイオン源スリットを通過して 磁場の前までの飛行中飞, 中性分子と衡突して, 電荷

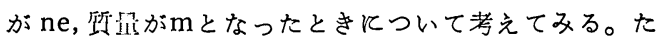
だし, 光速度を c として, 磁場の強さをHとする。

雪場Vで加速したときの傕動エネルギーは，

$$
\begin{aligned}
& \frac{1}{2} \mathrm{~m}_{0} \mathrm{v}^{2}=\mathrm{n}_{0} \mathrm{eV} \\
& \frac{\mathrm{m}_{0}}{\mathrm{n}_{0}} \mathrm{v}^{2}=2 \mathrm{eV}=\mathrm{k}=\mathrm{const}
\end{aligned}
$$

磁場H中を，速度 $\mathrm{v}$ のイオンが円運動するとき，1 オンの軌道半径をaとすれば，

$$
\mathrm{a}^{2}=\left(\frac{\mathrm{m}}{\mathrm{n}}\right)^{2} \cdot\left(\frac{\mathrm{c}}{\mathrm{eH}}\right)^{2} \mathrm{v}^{2}
$$

式(1)，(2)から Vを消去すると，

$$
\begin{aligned}
& \mathrm{a}^{2}=\left(\frac{\mathrm{m}}{\mathrm{n}}\right)^{2} \cdot\left(\frac{\mathrm{c}}{\mathrm{eH}}\right)^{2} \frac{\mathrm{n}_{0}}{\mathrm{~m}_{0}} \mathrm{k} \\
& \mathrm{a}^{2}=\frac{\mathrm{n}_{0}}{\mathrm{n}^{2}} \cdot \frac{\mathrm{m}^{2}}{\mathrm{~m}_{0}} \cdot\left(\frac{\mathrm{c}}{\mathrm{eH}}\right)^{2} \mathrm{k}
\end{aligned}
$$

式(3)から見掛の啠是をMとすれば，次式となる。

$$
\mathrm{M}=\frac{\mathrm{n}_{0}}{\mathrm{n}^{2}} \cdot \frac{\mathrm{m}^{2}}{\mathrm{~m}_{0}}
$$

$\mathrm{A}^{+2} \longrightarrow \mathrm{A}^{+2-1}$ の場合は, Norton10)が行つたよう 飞, 式(4)r $\mathrm{n}_{0}=2, \mathrm{~m}_{0}=40, \mathrm{n}=1, \mathrm{~m}=40$ を代入す ると，次式のようにアルゴンの場合の見掛けの質量が 80 となる

$$
\mathrm{M}_{A}=\frac{2}{(1)^{2}} \cdot \frac{(40)^{2}}{40}=80
$$

このようと，アルゴンの诅荷転移によって M/e80の 位置飞イオンが観测される㽞である。

3.4.1 王力と $\mathrm{M} / \mathrm{e}$ と 20，40，80との関係

武料を静動作した分析管飞䒚入して，圧力をB-Aダ ーシで测定し， $10^{-4} \mathrm{mmHg} \sim 10^{-5} \mathrm{mmHg}$ の簌囲内で 変化したときの，1オン赑と压力との関係を Fig. 12

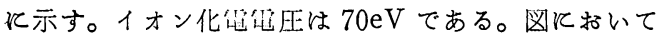
$\mathrm{M} / \mathrm{e} 20$ 打よび40のイオンの生成盕は压力と一次関係飞 ある。しかし MA80のイオンの生成占は20括よび40の よりる圧力に対する增加率が大きいことを示している。 80 のカーブが 20 括よび40のカープの約 2 倍の勾配を示

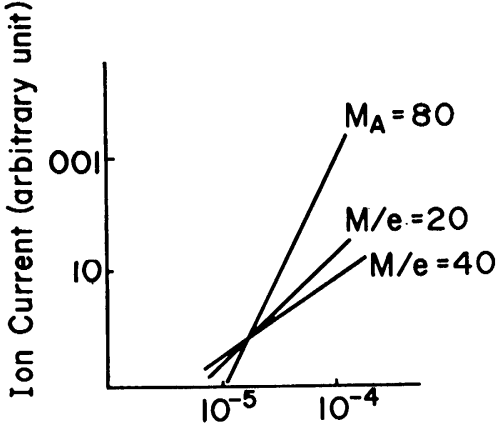

Pressure $(\mathrm{mmHg})$

Fig. 12. Pressure Deperdency of Ion Current

しているから生力に対して二次曲線であることが認め られる。测定值のバラッキは玨力の測定の不正確され よるるのである。すなわち MA80のイオンは二次反応 そよるものと判断される。

\subsubsection{1オンの加速'笔王とイオン㨁との関係}

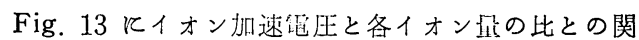
係を示した。これから 20/40の值がイオン加速䉓压に よらず一定であることは罗当な結果である。 $80 / 20$ 招 よび 80/40は加速電压飞比例して增大していることが わかった。つまりMA80のイオンはイオン加速電圧に 密接な関係があることがわかる。このことはイオンの 速度と $M / e 80$ の生成のための二次反忍の衝突断面蝵の 関係を示すのであろらが测定精度等不充分のため細か い議論はこの際差控えたい。

\subsection{4 イオン化電圧との関係}

$\mathrm{A}_{2}+$ のイオン化電压は $15.06 \mathrm{~V}, \mathrm{~A}^{+}$は15.76V, $\mathrm{A}^{++}$ は43.38Vである11)。M/e80の位置飞観測されるピー クの生成飞は次の 2 つの反応が考えられる。

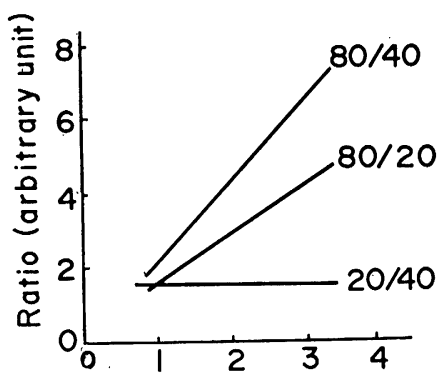

Ion Acceleration Voltage (KV)

Fig. 13. Characteristic Curves of Ion Current Ratio vs Ion Acceleration Volt 
Vol. 15, No. 2, Juue 1967

$$
\begin{aligned}
& \mathrm{A}+\mathrm{e} \longrightarrow \mathrm{A}^{++}+3 \mathrm{e} \\
& \mathrm{A}^{++}+\mathrm{A} \longrightarrow \mathrm{A}^{+2-1}+\mathrm{A}^{+} \\
& \mathrm{A}+\mathrm{e} \longrightarrow \mathrm{A}^{*}+\mathrm{e} \\
& \mathrm{A}^{*}+\mathrm{A} \longrightarrow \mathrm{A}_{2}{ }^{+}+\mathrm{e}
\end{aligned}
$$

ここでイオン化電圧約 $43 \mathrm{~V}$ 以下で $\mathrm{M}_{A} 80$ が出現すれ ば，これは(B)反応による $\mathrm{A}_{2}{ }^{+} 1$ オであるとほぼ断定 できる。また(A)反忍であれば $\mathrm{A}^{++}$のイオン化電圧 $43 \mathrm{~V}$ 以下では $\mathrm{M}_{A} 80$ は生成されず，43V 附近より急激と1 オンが生成はれるはずである。

Fig. 14 飞 $\mathrm{M}_{A} 80$ と $\mathrm{M} / \mathrm{e} 20$ のいわゆるイオン化効率 曲線を示す。イオン化電圧は特に較正してはいない。

Fig. 14 から分るようと M/e 20 と $\mathrm{M}_{A} 80$ のイオン生 成量とイオン化電圧との間には全く異った現象を示し ている。(I) の部分の $\mathrm{M}_{A} 80$ のイオンの出現電圧は約 $15 \mathrm{~V}$ であり，これから急激飞增大し，20～30Vで一定 となり，それからまた減少している。これは Melton

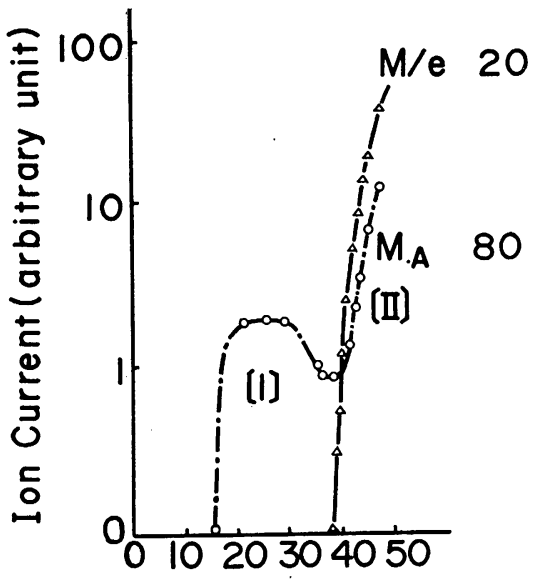

Ioning Everzy (eV)

Fig. 14. Ionization Efficiecy Curves of Argon

等の $\mathrm{A}_{2}+$ の生成カーブと傾向がよく一致しているので $\mathrm{A}_{2}+$ であるといえる。すなわち $(\mathrm{I})$ の部分は $(\mathrm{B})$ 反応

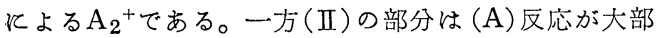
分である。これは $\mathrm{A}^{++}$のオン化電圧と (II)の部分の 延長から求められる出現電左とがほぼ一致することか らも証明し得る。(1)と (II)の谷は (1)と (II)の重畳と 考えられる。かかる曲線は $\mathrm{M}_{A} 80$ のイオンが $\mathrm{A}_{2}{ }^{+}$か $\mathrm{A}^{+2-1}$ を決定する重要な测定結果と思われる。

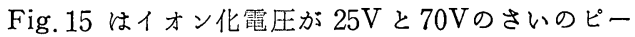
クの形を比較したものである。25Vの場合は(1)の (B) 反心による $\mathrm{A}_{2}{ }^{+}$イオンで鋭い形をしている。これはイ オン化箱内でアルゴ原子と励起されたアルゴン原子と が衝突して生成された $\mathrm{A}_{2}+1$ オが加速されるからで

ある。70Vのときはブロードなピークである。ブロード そなるのは一般に散乱現象と考えられる。とくに低質 量側飞尾を引くのは, Mattauch 等のいう磁場の洩漏 効果の外飞, 電荷転移の間飞速度変化したためである。

電荷転移の間飞, 速度が $\beta(0 \leqq \beta \ll 1)$ だけ変化して $\mathrm{v}=\mathrm{v}_{0}(1-\beta)$ となったとすると, 式 (4) は次のごとく なる

$$
\mathrm{M}=\frac{\mathrm{n}_{0}}{\mathrm{n}^{2}} \frac{\mathrm{m}^{2}}{\mathrm{~m}_{0}} \quad(1-2 \beta)
$$

$\beta$ が連続的な値をとるので低質量側飞尾をひいたピー クが観測される。

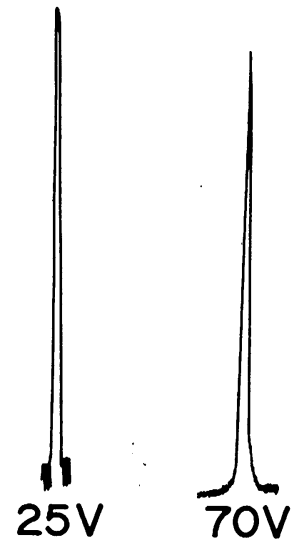

Fig. 15. Mass Spectra of Argon, $\mathrm{M}_{A}=80$

\section{4. 結言}

本装置はすでに製品化されていた日立極微マスによ る笑験をもとにして改良されたものである。金属製分 析管を用いた極微マスとしてほぼ満足すべき性能をう ることができた。実験結果として，核分裂放出ガスの 分析では末だ予備実験の段階にすぎないが，試料の作 製，测定上の問題点を見出すことができた。また真空 度の分解能飞与える影響打よびアルゴンの巽常ピーク 等の解明実験を有効飞実施できた。

終りに, 本試作研究飞拓いて御指導, 御討論頂いた 阪大緒方教授授, 阪府大早川教授, 都立大鹿又教授, またウランの分析の際御尽力くださった原研小森研究 員飞深謝する。

本研究は当日立中砳只野技師長, 阿部主管研究員の 御指導の下飞行われたるので, 神原所長, 谷口主任研 究員にはフイッンヨンガスの測定について直接御指示 を仰いだ。また広瀬研究員, 土井研究員飞は帮験上多 大の御援助を頂いた。その他本装置の設計製作を担当 され，応用研究についても，種々御指導下さった当所 
那珂工場の牧野工場長，野田主任技師，中島技師その 他関係者ととるにここに厚く御礼申上げる。

\section{文献}

1) J. H. Reynolds, Rev. Sci. Instr., 27, 928 (1956)

2）岡野純他，䓄是分析，No.15，16（1960）

3）岡部純他，斦员分析，No.18，87，（1961）

4）後藤正之，频号分析，No.18，95，（1961）

5）杉浦俊男他，所昆分析，No.24，141（1964）
6）谷口罴他，質量分析，No.27，163（1964）

7）津山斉他，質量分析，No.11，39（1958）

8) H. G. Thode et al., Canad. J. Research, 25, sec A. I (1947)

9) J. Mattauch et al., Physik Zeits., 40,16 (1936)

10) F. J. Norton, Natl. Bur. Standards Circ. No. 522, 201 (1953)

11) F. H. Field et al., Electron Impact Phenomena 217 (1957) 